\title{
Sengketa Pendaftaran Hak Milik Atas Tanah
}

\author{
Dewi Arnita Sari \\ Fakultas Syariah dan Hukum Islam \\ Institut Agama Islam Negeri Bone, Sulawesi Selatan, Indonesia \\ Email : Dewiarnitasari12@gmail.com
}

\begin{abstract}
This journal aims to find about Ownership disputes land rights Related to land registration in Makassar city. The purpose of this study is : 1. to analyze the factors affecting the dispute over ownership of land that has been registered in Makassar. 2. to analyze how far the solutions are provided by the government in resolving ownership of land that has been registered. This research is descriptive research with empirical juridical approach method. Research method used is method by using primary and secondary data with data collecting technique that are interview and questionnaire. The population of this study are the employee office of the state land agency Makassar and public figure. Sample in this research is 30 respondents by using technique purposive sampling. The results of this study shownthat : (1). the factors affecting the dispute over ownership of land are Legal factors, law enforcement factors, facilities and infrastructure factors. (2). There are two solutions are provided by the government in resolving ownership of land, that was The national land agency facilitates to do mediation and Solutions through the judiciary, negotiations, and others Depending on the perpetrators leading in the direction of a good solution to them. Recommendation of this research is Government is expectedPlay an active role So that people did not have problems in dispute signs in the future, that is Increased administration to be more thorough in making land certificates In order to minimize the dispute. Developing the training in order to increase human resource of law enforcer, socialization to public can be held in great quantities and all of reinforced facility supplying so that all of factor whom can influence presence of proprietary right dispute for estate can be minimalized.
\end{abstract}

Keywords : BPN; Land Registration; Ownership Disputes Land Rights

\begin{abstract}
Abstrak
Pendaftaran hak milik atas tanah, memberikan jaminan kepastian hukum kepemilikan hak atas tanah terhadap pemiik sah melalui penerbitan sertifikat tanah. Jurnal ini bertujuan untuk mengetahui tentang sengketa kepemilikan hak atas tanah terkait dengan pendaftaran tanah. Tujuan penelitian ini adalah : 1 . Untuk menganalisis faktor-faktor yang mempengaruhi terjadinya sengketa kepemilikan hak atas tanah yang telah didaftarkan di Makassar. 2. Untuk menganalisis sejauh manakah solusi yang disediakan oleh pemerintah dalam penyelesaian sengketa kepemilikan hak atas tanah yang telah didaftarkan. Penelitian ini adalah penelitian deskriptif dengan pendekatan yuridis empiris. Metode penelitian yang digunakan adalah metode kualitatif dengan menggunakan data primer dan sekunder dengan teknik pengumpulan data yakni wawancara dan
\end{abstract}


kuesioner. Hasil penelitian ini menunjukkan bahwa (1). Faktor-faktor yang mempengaruhi terjadinya sengketa kepemilikan hak atas tanah adalah faktor hukumnya, faktor penegak hukum, faktor sarana dan prasarana, faktor masyarakat serta faktor budaya. (2) Solusi penyelesaian sengketa kepemilikan hak atas tanah yang disediakan oleh pemerintah ada dua yakni solusi melalui Badan Pertanahan Nasional yang menfasilitasi untuk melakukan mediasi dan solusi melalui badan peradilan, bernegosiasi, dan lain-lain tergantung para pelakunya mengarahkan ke arah mana jalan penyelesaian yang baik menurutnya.

Kata Kunci : BPN; Pendaftaran Tanah; Sengketa Hak Atas Tanah

\section{A. Pendahuluan}

Undang-Undang Dasar 1945 secara eksplisit telah mengatur perihal hak asasi warga negara, dari sejumlah pasal terkait hak asasi warga negara dalam UUD 1945 tersebut, satu diantaranya adalah hak milik termasuk dalam hal ini adalah hak milik atas tanah. Ketentuan tersebut dicantumkan pada Pasal $28 \mathrm{H}$ Ayat (4) yang berbunyi: " Setiap orang berhak mempunyai hak milik pribadi dan hak milik tersebut tidak boleh diambil alih secara sewenang-wenang oleh siapapun". ${ }^{1}$ Hak asasi sebagaimana diatur di Pasal $28 \mathrm{H}$ tersebut memberikan jaminan kepemilikan berupa hak untuk memiliki dan perlindungan negara terhadap hak milik tersebut. Dengan di aturnya ketentuan dalam pasal tersebut maka sebagai tindak lanjutnya diundangkanlah Undang-Undang Nomor 5 Tahun 1960 tentang Peraturan Dasar Pokok-pokok Agraria (UUPA). ${ }^{2}$

Dalam rangka pemberian jaminan kepemilikan hak atas tanah sebagaimana yang termaktub dalam Undang-Undang Dasar Tahun 1945 dan Undang-Undang No. 5 Tahun 1960 Tentang Peraturan Pokok-Pokok Agraria (UUPA) maka di terbitkanlah Peraturan Pemerintah No. 24 Tahun 1997 sebagai aturan pelaksana, yang kemudian menerangkan bahwa setiap warga negara, guna mendapatkan jaminan hak atas tanah yang dimilikinya maka harus mendaftarkan tanah tersebut terlebih dahulu yang kemudian oleh pemerintah akan di terbitkan sertifikat tanah sebagai bukti kepemilikan hak atas tanah tersebut. Sebagaimana

\footnotetext{
${ }^{1}$ Republik Indonesia, Undang-Undang Dasar Negara Republik Indonesia Tahun 1945 (Sekretariat Jenderal MPR RI, 2002).

${ }^{2}$ Della Monika, “Analisis Yuridis Eksistensi Pejabat Pembuat Akta Tanah (PPAT) Dalam Perspektif Pendaftaran Tanah Di Kecamatan Tanjungpinang Timur (Studi Penelitian Dikantor Notaris Dan Pejabat Pembuat Akta Tanah Afika Hersany)," Jurnal Selat 7, no. 1 (2019): 65-86.
} 
yang telah dijelaskan di atas bahwa dengan melakukan pendaftaran tanah, pemilik tanah telah memberikan jaminan kepastian hukum kepemilikan hak atas tanah terhadap dirinya sendiri melalui penerbitan sertifikat tanah oleh pemerintah, yang meliputi kepastian hak, kepastian objek dan kepastian subjek termasuk administrasi pendaftaran dan penerbitan sertifikat. ${ }^{3}$ Adanya jaminan hak atas tanah sebagaimana dijelaskan diatas, pada realitasnya lazim dijumpai adanya pemilik tanah yang enggan untuk melakukan pendaftaran hak milik atas tanah sebagaimana mestinya. Hal tersebut disebabkan oleh berbagai macam faktor seperti proses yang terlalu panjang, serta menghabiskan waktu dan biaya yang tidak sedikit. ${ }^{4}$

Di Makassar misalnya maupun di wilayah lainnya di Indonesia, seringkali didapati kasus masyarakat yang merasa berhak atas sebidang tanah, karena ingin menjualnya maka diuruslah sertifikat atas pemilik yang baru namun ketika didaftarkan, ternyata tanah tersebut milik orang lain yang memiliki sertifikat yang sama atas sebidang tanah itu. Berdasar kenyataan tersebut, maka secara tidak langsung tentu akan berdampak pada potensi lahirnya sengketa kepemilikan hak atas tanah yang diakibatkan oleh tidak terdaftarnya tanah yang dimiliki. Selain daripada itu, terdapat pula pihak-pihak tertentu baik perseorangan atau kelompok (mafia tanah) demi menguasai tanah milik orang lain seringkali melakukan klaim sepihak tanpa melalui proses hukum ataupun melalui mekanisme hukum yang berlaku. Kondisi tersebut, tentu menjadi tantangan tersendiri dalam upaya pemberian jaminan hak atas kepemilikan tanah oleh pemerintah melalui penerapan Undang-Undang Pokok Agraria.

Disisi lain, Badan Pertanahan Nasional (BPN) selaku instasi yang diamanahkan dan diharapkan dapat mengatasi permasalahan pertanahan, belum mampu memberikan kepastian hukum terhadap kepemilikan hak atas tanah oleh masyarakat, hal ini terlihat dari banyaknya sengketa kepemilikan hak atas tanah yang terjadi hingga tahun 2018. Secara nasional, berdasarkan data Kementerian

\footnotetext{
${ }^{3}$ Felishella Earlene and Jesslyn Evelina Tandrajaya, "Sengketa Penguasaan Tanah Antara Warga Kapuk Poglar RT 07/RW 04 Jakarta Barat Dengan Polda Metro Jaya Ditinjau Dari Perspektif Hak Asasi Manusia," Cepalo 3, no. 2 (2019).

${ }^{4}$ Sutedi Adrian,2012, Sertifikat Hak Atas Tanah, Sinar Gafika.
} 
Agraria dan Tata Ruang/ Badan Pertanahan Nasional, menyebutkan bahwa di tahun 2018 terdapat 6.071 kasus sengketa tanah yang sifatnya antar perorangan, 2.866 kasus sengketa tanah antara masyarakat dengan pemerintah dan 66 kasus sengketa tanah antar kelompok masyarakat. ${ }^{5}$ Sedangkan ditahun 2019, jumlah permasalahan tanah di Indonesia berada diangka 8.959 kasus yang meliputi sengketa, konflik, dan perkara. Dari total 8.959 kasus, 56\% dari jumlah konflik tersebut merupakan konflik antar masyarakat. ${ }^{6}$

Permasalahan-permasalahan sengketa kepemilikan hak atas tanah harus diperhatikan oleh pemerintah agar kepastian hukum terhadap kepemilikan hak atas tanah dapat terjamin. Untuk itu penulis merasa permasalahan ini menarik sehingga penulis mengkaji masalah ini dengan judul "Sengketa Pendaftaran Hak Milik Atas Tanah”.

\section{B. Metode Penelitian}

Penelitian ini merupakan penelitian hukum empiris dengan menjadikan sengketa kepemilikan hak atas tanah sebagai objek kajian serta keseluruhan pegawai kantor Badan Pertanahan Kota Makassar dan masyarakat sebagai populasinya. serta dengan menggunakan cara purposive sampling (teknik nonrandom sampling). ${ }^{7}$ Data yang diperoleh penulis kemudian dianalisis secara kualitatif. Adapun data yang dimaksud adalah data hasil wawancara, penelususran peraturan perundang-undangan yang memiliki keterkaitan dengan objek penelitian serta berbagai bahan pustaka. Data yang diperoleh kemudian disusun dan dibuat dalam bentuk data kemudian menghasilkan kajian data secara kualitatif yang seterusnya diambil kesimpulan atau verifikasi.

\section{Hasil Penelitian dan Pembahasan}

\section{Faktor-Faktor yang Berpengaruh Terhadap Sengketa Hak Atas Tanah}

5 Kompas.com, Sengketa Tanah antar perorangan tembus 6071 Kasus. Sumber: https://properti.kompas.com/read/2018/12/18/125954021/sengketa-tanah-antar-perorangantembus-6071-kasus, diakses 18 Juli 2020

${ }^{6}$ Okezone, "Ada 8.959 Sengketa Lahan Terbanyak Konflik Antar Masyarakat," 2019, last modified 2019, https://economy.okezone.com/read/2019/05/03/470/2051073/ada-8-959sengketa-lahan-terbanyak-konflik-antar-masyarakat. (2016).

7 Said Sampara, "La Ode Husen," Metode Penelitian Hukum. Makassar: Kretakupa 
Pendaftaran tanah perlu dilakukan untuk memberikan kepastian hukum terhadap orang yang menguasai dan memiliki tanah agar nantinya mempunyai kekuatan hak didepan hukum dan negara. Namun sengketa hak atas tanah dapat terjadi karena adanya faktor-faktor yang mempengaruhi yakni:

\section{a. Faktor Hukumnya}

Bernhard Limbong secara khusus menguraikan beberapa faktor dalam hukum yang menurutnya sebagai akar permasalahan dalam bidang pertanahan $^{8}$ yakni: (i) Regulasi kurang memadai, (ii) Tumpang tindih peradilan, (iii) Tumpang tindihnya peraturan. Berdasarkan pada aturan hukum atau undang-undang, penegakan hukum menurut Soerjono Soekanto disebabkan oleh, pertama Pemberlakukan undang-undang tidak didasarkan pada asas-asas hukum. Kedua, Penerapan Undang-Undang yang berdasarkan tingkat urgensinya belumlah di butuhkan, dan yang ketiga , bahasa yang digunakan serta pemilihan kata- kata yang cenderung multitafsir sehingga menyulitkan aparat penegak hukum untuk menerapkannya. $^{9}$

\section{Tabel 1}

Jawaban Responden Tentang Pengaruh Faktor Hukumnya Terhadap Kasus Sengketa Tanah

\begin{tabular}{cccc}
\hline No & Jawaban Responden & Frekuensi & Persentase \\
\hline $\mathbf{1}$ & Sangat berpengaruh & 18 & 60 \\
$\mathbf{2}$ & Kurang Berpengaruh & 9 & 30 \\
$\mathbf{3}$ & Tidak Berpengaruh & 3 & 10 \\
& $\quad$ Jumlah & 30 & 100 \\
\hline
\end{tabular}

Sumber data :Hasil Olah Data Primer, Tahun 2020

Berdasarkan data penelitian diatas (table 1), menunjukkan bahwa 60\% dari 30 sampel menjawab berpengaruh. Dan 30\% menjawab kurang berpengaruh. Sedangkan yang menjawab tidak berpengaruh hanya $10 \%$.

\footnotetext{
${ }^{8}$ Bernard Limbong, Teori Sosiologi Modern (Jakarta: Prestasi Pustaka, 2001).

${ }^{9}$ Soerjono Soekanto, Pengantar Penelitian Hukum (Penerbit Universitas Indonesia (UIPress), 2006).
} 
Dengan demikian jika dikaitkan dengan teori-teori hukum yang telah dijelaskan sebelumnya, maka dapat dijumpai adanya kesesuaian antara data yang di peroleh dalam penelitian ini dan teori-teori para pakar tersebut, dengan kata lain hukum sangat mempengaruhi terjadinya kasus sengketa pertanahan di kota Makassar. Hal tersebut dikarenakan latar belakang maupun motif dalam melakukan penafsiran suatu peraturan atau undangundang yang berkaitan dengan pertanahan, antara orang satu dengan lainnya bisa saja berbeda bilamana penggunaan bahasa dan penyusnan kalimat yang tidak jelas dan tegas terhadap suatu hal.

\section{b. Faktor Penegaknya}

Dalam teori keadilan sebagaimana yang di ungkapkan oleh John Rawls memberikan pemahaman terkait salah satu bentuk keadilan yang disebutnya sebagai fairness yakni dengan memandang netral kepada semua pihak yang melanggar hukum. ${ }^{10}$ Berdasar pada pengertian tersebut maka dapat dipahami bahwa aparat pengak hukum haruslah memberikan perlakuan yang sama terhadap semua orang, dengan kata lain tidak mengistimewakan seseorang atau kelompok tertentu dari orang atau kelompok lainnya.

Sedangkan oleh Gustav Radbruch, yang merupakan salah seorang ahli hukum Jerman menyebutkan bahwa, "Recht ist Wille Zur Gerechtigkeit", pernyataan tersebut memberikan makna bahwa hukum pada dasarnya bertujuan untuk mewujudkan keadilan. Atau denga kata lain bahwa kehadiran hukum positif disuatu negara adalah guna mewujudkan nilai-nilai moral yang hidup dalam masyarakat khususnya terkait nilai keadilan.

Kasubsi Sengketa dan Konflik Pertanahan yaitu Ibu Asih Lestari mengatakan bahwa salah satu penyebab timbulnya sengketa pertanahan yakni karena administrasi yang tidak benar di kelurahan ataupun adanya ketidak jujuran aparat desa/kelurahan. Disamping itu, Muhammad Ramli yang merupakan salah satu tokoh masyarakat mengatakan bahwa

${ }^{10}$ John Rawls, 2016, Teori Keadilan: Dasar-Dasar Filsafat Politik Untuk Mewujudkan Kesejahteraan Sosial Dalam Negara, Yogyakarta: Pustaka Pelaja. Hal. 15 
kecenderungan timbulnya sengketa tanah juga disebabkan karena ketidaktelitian oknum BPN dalam hal pendaftaran maupun penyelesaian sengketa tanah, sehingga menurut beliau selain keterampilan, maka etika dan moralitas dari setiap aparat penegak hukum memiliki andil yang besar terhadap timbulnya sengketa di bidang pertanahan. (wawancara 6 Januari 2020).

Tabel 2

Jawaban Responden Tentang Pengaruh Penegak Hukum Terhadap Kasus Sengketa Tanah

\begin{tabular}{llcc}
\hline No & Jawaban Responden & Frekuensi & Persentase \\
\hline $\mathbf{1}$ & Sangat berpengaruh & 15 & 50 \\
$\mathbf{2}$ & Kurang Berpengaruh & 11 & 37 \\
$\mathbf{3}$ & Tidak Berpengaruh & 4 & 13 \\
& & & \\
& Jumlah & 30 & 100 \\
\hline
\end{tabular}

Sumber data : Hasil Olah Data Primer, Tahun 2020

Berdasarkan data penelitian dalam table 2 tersebut diatas menunjukkan bahwa 50\% dari 30 sampel menjawab berpengaruhnya faktor aparat penegak hukum, 37\% menganggap kurang berpengaruh dan hanya $13 \%$ menganggap tidak memiliki pengaruh. Jika mengaitkan antara teori-teori hukum sebagaimana yang telah dijelaskan pada sub bab sebelumnya maka dapat disimpulkan bahwa antara data dan teori-teori tersebut memiliki kesesuaian sehingga munculnya sengketa dalam bidang pertanahan serta dalam penyelesaian kasus sengketa tanah di kota Makassar sangatlah dipengaruhi oleh faktor penegak hukum. Untuk itu aparat penegak hukum harus mengedepankan aspek sumber daya manusia serta etika dan moral sebab para penegak hukumlah yang menentukan berjalan dengan baiknya sebuah hukum.

\section{c. Faktor Sarana dan Prasarana}

Sarana dan prasarana merupakan salah satu aspek yang mempengaruhi penegakan hukum, adapun sarana dan prasarana yang 
dimaksud yakni sumber daya manusia yang terampil, wadah dan penata kelolaan yang baik, serta peralatan, keuangan dan seterusnya, hal ini bisa saja menghambat proses penegakan hukum bilamana tidak dipenuhi. ${ }^{11}$ Berikut data pengaruh sarana dan prasarana:

\section{Tabel 3}

Jawaban Responden Terhadap Pengaruh Sarana Dan Prasarana Dalam Menghindari Terjadinya Sengketa Tanah

\begin{tabular}{|c|c|c|c|}
\hline No & Jawaban Responden & Frekuensi & Persentase \\
\hline 1 & Sangat berpengaruh & 19 & 63 \\
\hline 2 & Kurang Berpengaruh & 8 & 27 \\
\hline \multirow[t]{2}{*}{3} & Tidak Berpengaruh & 3 & 10 \\
\hline & Jumlah & 30 & 100 \\
\hline
\end{tabular}

Sumber data : Pengolahan Data Primer, Tahun 2020

Berdasar pada data penelitian tersebut diatas (tabel 3) menunjukkan bahwa $63 \%$ dari 30 sampel menjawab berpengaruhnya faktor ini, 27\% merasa faktor ini kurang berpengaruh dan 10\% menganggap faktor sarana dan prasarana ini tidak berpengaruh. Jika dikaitkan dengan teori yang telah dijelaskan diatas maka terdapat kesesuaian antara data hasil penelitian dan teori tersebut sehingga faktor sarana dan prasarana sangat mempengaruhi terjadinya sengketa dalam bidang pertanahan serta dalam penyelesaian kasus sengketa tanah di kota Makassar. Hal ini tergambar dengan adanya kasus sengketa dalam bidang pertanahan atau kepemilikan hak atas tanah yang bersumber dari terbitnya sertifikat ganda, meskipun pada dasarnya sarana dan prasarana bukanlah faktor tunggal atas terbitnya sertifikat ganda, namun dengan sarana dan prasarana yang baik akan mampu meminimalisir potensi terbitnya sertifikat ganda.

Menurut penulis sendiri faktor sarana dan prasarana merupakan faktor yang sangat penting dalam hal pendaftaran hak atas tanah karena

11 Soerjono Soekanto,1983, Faktor-Faktor Yang Mempengaruhi Penegakan Hukum Rajawali. Jakarta.hal 25 
dengan tersedianya fasilitas yang baik akan mendukung pelaksanaan tugas dengan optimal.

\section{d. Faktor Masyarakat}

Hasil penelitian menunjukkan $80 \%$ dari 30 sampel mengatakan bahwa faktor ini berpengaruh, 16\% menganggap faktor ini kurang berpengaruh dan $4 \%$ mengatakan kalau faktor masyarakat tidak berpengaruh. Dapat disimpulkan bahwa hal ini berarti faktor masyarakat sangat berpengaruh terhadap timbulnya sengketa pertanahan. Salah satunya ialah kesadaran masyarakat akan pentingnya pendaftaran kepemilikan hak katas tanah. Data tersebut dapat dilihat pada tabel berikut:

Tabel 4

Jawaban Responden Tentang Pengaruh Masyarakat Terhadap Sengketa Kepemilikan Hak Atas Tanah

\begin{tabular}{cccc}
\hline No & Jawaban Responden & Frekuensi & Persentase \\
\hline $\mathbf{1}$ & Sangat berpengaruh & 24 & 80 \\
$\mathbf{2}$ & Kurang Berpengaruh & 5 & 16 \\
$\mathbf{3}$ & Tidak Berpengaruh & 1 & 4 \\
& & 30 & 100 \\
\hline
\end{tabular}

Sumber data : Hasil Olah Data Primer, Tahun 2020

Belum terbangunnya kesadaran masyarakat atas hukum dengan baik, hal ini dikarenakan masih dialaminya krisis kepercayaan oleh sebagian masyarakat kepada hukum maupun penegaknya. Pemahaman masyarakat terhadap penyelesaian sengketa kepemilihan atas tanah masih sangat rendah, diduga hal ini juga karena kurangnya sosialisasi mengenai masalah pertanahan kepada masyarakat. Masyarakat masih apatis untuk melakukan pendaftaran tanah. Masyarakat hanya menganggap bahwa masalah penguasaan tanah hanya bertitik tolak pada surat dari kepala desa atau kelurahan dan tidak pernah memikirkan akibat dari pada penguasaan tanah terhadap anak cucu mereka. 
Menurut penulis faktor masyarakat sangat berpengaruh dalam hal sengketa pertanahan karena masyarakat merupakan pemangku kepentingan sebagai penguasaan terhadap tanah secara defacto.

\section{e. Faktor Budaya}

Adanya budaya atau adat yang masih sangat kental dalam diri masyarakat yang memandang bahwa pendaftaran tanah merupakan hal yang tidak penting. Kondisi masyarakat juga mempengaruhi proses sehingga terjadinya sengketa kepemilikan hak atas tanah karena masyarakat menempatkan pendaftaran tanah sebagai sesuatu kebutuhan yang tidak penting. Masyarakat lebih memelihara sistem kepercayaan baik secara adat, maupun dalam suatu lingkungan tertentu. Faktor budaya berpengaruh dalam terjadinya sengketa kepemilikan atas tanah, hal ini didukung dengan data yang menunjukkan 63\% dari 30 sampel mengatakan bahwa faktor budaya ini berpengaruh dalam hal terjadinya sengketa tanah. Data tersebut dapat dilihat pada tabel berikut :

Tabel 5

Jawaban Responden Tentang Pengaruh Budaya

Terhadap Terjadinya Kasus Sengketa Kepemilikan Hak Atas Tanah

\begin{tabular}{|c|c|c|c|}
\hline No & Jawaban Responden & Frekuensi & Persentase \\
\hline 1 & Sangat berpengaruh & 19 & 63 \\
\hline 2 & Kurang Berpengaruh & 7 & 23 \\
\hline \multirow[t]{2}{*}{3} & Tidak Berpengaruh & 4 & 14 \\
\hline & Jumlah & 30 & 100 \\
\hline
\end{tabular}

Sumber data : Data Primer yang diolah, Tahun 2020

Dari data tersebut menunjukkan bahwa pengaruh budaya sangat besar karena hanya $23 \%$ masyarakat yang menganggap budaya kurang berpengaruh dan $14 \%$ mengatakan tidak berpengaruh sama sekali.

\section{Solusi Penyelesaian Sengketa Hak Milik Atas Tanah}

\section{a. Solusi Melalui Mediasi}

Penyelesaian sengketa tanah ini selain dapat diselesaikan melalui jalur litigasi juga dapat diselesaikan dengan jalur non litigasi. Salah satu 
penyelesaian sengketa tersebut diselesaikan dengan proses mediasi. Mediasi adalah salah satu dari proses alternatif penyelesaian masalah dengan bantuan pihak ketiga (mediator) melalui prosedur yang disepakati oleh para pihak difasilitasi untuk dapat tercapai suatu solusi yang menguntungkan para pihak. Namun solusi ini jarang menjadi pilihan masyarakat modern untuk meyelesaikan masalah sengketa tanah. Solusi ini biasa digunakan oleh masyarakat adat atau yang berkaitan dengan sengketa tanah adat. Sedangkan masyarakat modern lebih banyak memilih penyelesaian sengketa dengan jalur litigasi atau melalui peradilan.

\section{b. Solusi Melalui Badan Pertanahan Nasional}

Penyelesaian sengketa pertanahan dapat diajukan ke Badan Pertanahan Nasional dengan ketentuan bahwa munculnya kasus pertanahan yang diajukan merupakan akibat dari adanya tuntutan dari warga baik orang maupun badan hukum akibat dari diterbitkannya keputusan tata usaha negara oleh pejabat tata usaha negara, yang menimbulkan kerugian bagi masyarakat, adapun pejabat tata usaha negara yang dimaksud adalah pejabat tata usaha negara yang berada dalam lingkungan Badan Pertanahan Nasional selaku instansi yang berwenang mengurusi perihal pertanahan. ${ }^{12}$

Prosedur penyelesaian sengketa melalui Badan Pertanahan Nasional yakni; dengan adanya permohonan yang yang diajukan kepada badan pertanahan nasional selanjutnya oleh Kepala Badan Pertanahan Nasional melakukan koreksi atas terbitnya suatu keputusan Tata Usaha Negara di bidang pertanahan yang oleh atau atas dasar keputusan tersebut timbul, hilang atau terganggunya hak atas tanah. Ketika telah diterimanya berkas pengaduan dari masyarakat tersebut, kemudian diadakannya pengumpulan data serta penelitian atas berkas tersebut oleh pejabat yang berwenang. Selanjutnya menyimpulkan sementara hasil pemeriksaan berkas permohonan, apakah permohonan keberatan tersebut dapat diteruskan proses penyelesaiannya atau tidak, dalam hal penyampaian permohonan keberatan secara langsung ke

12 Afia Ismail, 2017, Penyelesaian Sengketa Tanah, Sumedang: IPDN Kampus Jatinangor.hal.1 
kantor Badan Pertanahan Nasional dan oleh Badan Pertanahan Nasional berkas permohonan dinyatakan belum lengkap dan masih kurang jelas maka akan diminta oleh pihak Badan Pertanahan Nasional kepada kepala kantor Badan Pertanahan Kabupaten/Kota penjelasan disertai data-data penunjang. ${ }^{13}$

Dengan menyampaikan kasus konflik atau sengketa pertanahan ke Badan Pertanahan Nasional untuk diselesaikan, maka oleh Badan Pertanahan Nasional akan diselesaikan dengan metode mediasi yakni dengan memanggil para pihak yang bersengketa. ${ }^{14}$

Kasubsi Sengketa dan Konflik Pertanahan yaitu Ibu Asih Lestari mengatakan bahwa sesuai Peraturan Menteri Agraria Dan Tata Ruang Nomor 11 Tahun 2016, Badan Pertanahan Nasional bisa memfasilitasi penyelesaian sengketa melalui mediasi antara pihak-pihak yang terlibat sengketa. Dalam hal, upaya penyelesaian sengketa yang dimohonkan kepada Badan Pertanahan Nasional melalui mediasi tersebut memperoleh hasil berupa kesepakatan mufakat, adapun kesepakan tersebut terdiri dari surat pemberitahuan hasil mediasi, berita acara rapat, serta akta yang dibuat dihadapan notaris.

Sedangkan dalam hal, pemeriksaan yang dilakukan oleh Badan Pertanahan Nasional terhadap keputusan pejabat tata usaha Negara dalam bidang pertanahan yang kemudian dimohonkan penyelesaian ke Badan Pertanahan Nasional mendapatkan hasil bahwa keputusan tersebut baik materil maupun formil pembuatan keputusan telah sesuai dan dibuat berdasarkan mekanisme yang baik dan benar, maka Badan Pertanahan Nasional dapat memberikan putusan berupa pernyataan menolakan permohonan yang diajukan oleh pemohon.

Putusan yang diberikan oleh Badan Pertanahan Nasional berupa penolakan permohonan pemohon, dapat di ajukan ke pengadilan sebagai upaya hukum yang tersedia, yang selanjutnya penyelesaian sengketa dilakukan dengan melalui proses peradilan, dalam sengketa yang timbul karena adanya pembebasan lahan oleh pemerintah maka objek sengketa

${ }^{13}$ Mujiarjo, "Pendaftaran Tanah," Scribd.

${ }^{14}$ Herawan Sauni, "Konflik Penguasaan Tanah Perkebunan," University Of Bengkulu Law Journal 1, no. 1 (2016): 45-67. 
tersebut tidak boleh dilakukan mutasi terhadapnya yang bisa saja merugikan pihak yang bersengketa, sampai adanya putusan hakim yang berkekuatan hukum tetap. Adapun ketika putusan hakim telah berkekuatan hukum tetap mengabulkan permohonan/tuntutan pemohon, maka tahapan selanjutnya ialah usulan permohonan pembatalan atas keputusan tata usaha negara yang sebelumnya telah diterbitkan kepada kepala kantor pertanahan kabupaten kota. $^{15}$

Penulis sendiri berpendapat bahwa penyelesaian sengketa melalui BPN ini merupakan salah satu langkah tepat dalam menyelesaikan masalah pertanahan karena langsung ditangani oleh instansi yang menangani. Walaupun sebenarnya mediasi secara adat atau kekeluargaan dapat dilakukan terlebih dahulu.

\section{c. Solusi Melalui Badan Peradilan}

Jika penyelesaian masalah pertanahan melaui Badan Pertanahan Nasional dianggap masyarakat tidak memuaskan maka masyarakat dapat menyelesaikannya melalui badan peradilan. Dan pada realitasnya mayoritas masyarakat yang bersengketa lebih memilih menempuh jalur pengadilan dalam menyelesaikan sengketa (perhatikan table 6).

\section{Tabel 6}

Jumlah Kasus Sengketa Kepemilikan Hak Atas Tanah Di Kota Makassar Tahun 2017-2019

\begin{tabular}{ccc}
\hline Tahun & Jumlah Kasus & Persentase \\
\hline $\mathbf{2 0 1 7}$ & 373 & 24 \\
$\mathbf{2 0 1 8}$ & 398 & 26 \\
$\mathbf{2 0 1 9}$ & 410 & 28 \\
Jumlah & 1518 & 100 \\
\hline
\end{tabular}

Sumber data : Pengadilan Negeri Makassar, 2020

15 Anton Advetus Kacaribu 2017, Suatu Tinjauan Mengenai Sengketa Hak Atas Tanah, Sumatra Utara. 
Dari table 6 diatas menggambarkan bahwa dari tahun 2017 sampai 2019 kasus sengketa tanah mengalami peningkatan yakni $24 \%$ ditahun 2017, meningkat 26\% ditahun 2018 dan meningkat lagi ditahun 2019 sebanyak 28\%. Terjadi peningkatan sengketa hak atas tanah setiap tahunnya, ini menunjukkan bahwa adanya perubahan yang semakin tinggi terhadap kebutuhan akan tanah yang berdampak pada peningkatan sengketa dalam bidang pertanahan serta membuktikan bahwa mayoritas masyarakat lebih memilih penyelesaian sengketa melalui badan peradilan daripada menyelesaikan sengketa pertanahan pada tahap solusi mediasi yang difasilitasi oleh Badan Pertanahan Nasional.

Jika penyelesaian melalui mediasi antar para pihak yang bersengketa tak menemukan titik temu serta upaya penyelesaian sepihak oleh Kepala Badan Pertanahan Nasional tidak pula menyelesaikan sengketa, maka satusatunya jalan terakhir yang dapat ditempuh adalah penyelesaian sengketa kepemilihan tanah melalui jalur pengadilan. ${ }^{16}$ Perlu di ingat bahwa pencabutan atau pembatalan sertikat tanah atau surat keputusan terkait hak atas tanah merupakan kewenangan administratif Kepala Badan Pertanahan Nasional, sehingga apabila terjadi kondisi dimana putusan hakim dalam penyelesian sengketa melalui jalur peradilan, tidak dapat dilaksanakan maka kepala Badan Pertanahan Nasional dapat mengeluarkan kebijakan terkait kondisi tersebut.Berdasar pada uraian hasil penelitian tersebut diatas maka dapat di simpulkan bahwa Badan Pertanahan Nasional masih menguasai urusan pertanahan selama ini sebagai instansi vertikal namun tetap saja sering terjadi perbedaan fungsi lahan yang mengakibatkan kerugian dialami oleh masyarakat maupun investor karena izin yang diberikan oleh pihak BPN tidak terintegrasi dengan rencana tata ruang kota sehingga lahan yang dimiliki masyarakat terbatas dalam pemanfaatannya. ${ }^{17}$

\footnotetext{
${ }^{16}$ Irawan Soerodjo, 2003 Kepastian Hukum Pendaftaran Hak Atas Tanah Di Indonesia Arkola. Surabaya hal.187

${ }^{17}$ Eko Noer Kristiyanto, "Implementasi Kearifan Lokal Sunda Dalam Penataan Ruang Menurut Undang-Undang Nomor 26 Tahun 2007 Tentang Penataan Ruang: Studi Di Bandung Jawa Barat," Jurnal Penelitian Hukum De Jure 18, no. 2 (2018): 205-218.
} 
Menyikapi hal tersebut maka pemerintah melakukan perombakan instansi guna menciptakan penatakelolaan yang baik dan terintegrasi, yakni dengan menggabungkan Badan Pertanahan Nasional dan direktorat jenderal tata ruang kementrian pekerjaan umum kedalam kementrian agraria dan tata ruang, hal ini menjadi angin segar di kalangan masyarakat sehingga tak perlu khawatir lagi mengenai akan terjadinya perbedaan fungsi lahan karena pemberian izin lahan dan pengendalian tata ruang telah ditentukan oleh satu organisasi yang sama.

Menurut penulis sendiri bahwa Badan Pertanahan selaku instansi pemerintah yang harus memberikan pelayanan terhadap pendaftaran tanah dengan proses yang sederhana, mudah dan cepat. Agar masyarakat dapat mendapatkan hak kepemilikan atas tanahnya yang sah dengan pelayanan yang optimal.

\section{Penutup}

Berdasarkan hasil penelitian penulis, maka disimpulkan bahwa faktorfaktor yang berpengaruh terhadap sengketa dalam bidang pertanahan adalah faktor hukumnya yaitu regulasi yang multitafsir. Faktor penegak hukumnya yakni ketidakjujuran aparat. Faktor sarana dan prasarana yaitu fasilitas yang tepat dan efektif. Faktor masyarakat yaitu pemahaman tentang hukum yang kurang. Faktor budaya yaitu kebiasaan-kebiasaan dan cara berfikir penegak hukum dan masyarakat yang buruk. Dan adapun penyelesaian sengketa dalam bidang pertanahan dapat melaui: (1) mediasi (2) Badan Pertanahan Nasional dan (2) melalui lembaga peradilan. Dengan melihat tingginya jumlah kasus pertanahan, yang setiap tahun meningkat, maka saran penulis yaitu perlu kiranya dilakukan evaluasi yang menyeluruh agar dapat meminimalisir timbulnya sengketa kepemilikan hak atas tanah. Memperbanyak pelatihan dalam rangka peningkatan SDM para penegak hukum, sosialisasi kepada masyarakat diperbanyak serta pengadaan fasilitas yang mendukung agar semua faktor-faktor yang mempengaruhi adanya sengketa kepemilikan hak atas tanah bisa diminimalisir. 


\section{Daftar Pustaka}

\section{Buku}

Adrian, Sutedi. 2012, Sertifikat Hak Atas Tanah. Sinar Gafika, Jakarta.

Ismail, Afia. 2017, Penyelesaian Sengketa Tanah. Sumedang: IPDN Kampus Jatinangor.

Kacaribu, Anton Advetus. 2017, Suatu Tinjauan Mengenai Sengketa Hak Atas Tanah. Sumatra Utara..

Limbong, Bernard. 2001, Teori Sosiologi Modern. Prestasi Pustaka, Jakarta.

Mujiarjo. Pendaftaran Tanah. Scribd.

Rawls, John. 2006 Teori Keadilan: Dasar-Dasar Filsafat Politik Untuk Mewujudkan Kesejahteraan Sosial Dalam Negara, Pustaka Pelajar, Yogyakarta.

Sampara, Said. La Ode Husen. 2016, Metode Penelitian Hukum. Kretakupa, Makassar

Soekanto, Soerjono 1983, Faktor-Faktor Yang Mempengaruhi Penegakan Hukum. Rajawali Jakarta.

_. 2006, Pengantar Penelitian Hukum. Penerbit Universitas Indonesia (UIPress), Jakarta.

Soerodjo, Irawan. 2003, Kepastian Hukum Pendaftaran Hak Atas Tanah Di Indonesia. Arkola, Surabaya.

\section{Artikel/Jurnal}

Earlene, Felishella, and Jesslyn Evelina Tandrajaya. "Sengketa Penguasaan Tanah Antara Warga Kapuk Poglar RT 07/RW 04 Jakarta Barat Dengan Polda Metro Jaya Ditinjau Dari Perspektif Hak Asasi Manusia.” Cepalo 3, no. 2 (2019).

Kristiyanto, Eko Noer. "Implementasi Kearifan Lokal Sunda Dalam Penataan Ruang Menurut Undang-Undang Nomor 26 Tahun 2007 Tentang Penataan Ruang: Studi Di Bandung Jawa Barat." Jurnal Penelitian Hukum De Jure 18, no. 2 (2018): 205-218

Monika, Della. "Analisis Yuridis Eksistensi Pejabat Pembuat Akta Tanah (PPAT) Dalam Perspektif Pendaftaran Tanah Di Kecamatan Tanjungpinang Timur (Studi Penelitian Dikantor Notaris Dan Pejabat Pembuat Akta Tanah Afika Hersany)." Jurnal Selat 7, no. 1 (2019): 65-86.

Sauni, Herawan. "Konflik Penguasaan Tanah Perkebunan." University of Bengkulu Law Journal 1, no. 1 (2016): 45-67.

Undang-Undang Dasar 1945

UU Nomor 5 Tahun 1960 Tentang Peraturan dasar Pokok-Pokok Agraria

Peraturan Pemerintah Nomor 24 Tahun 1997 Tentang Pendaftaran Tanah

Peraturan Presiden Republik Indonesia Nomor 20 Tahun 2015 perubahan atas Peraturan Presiden Nomor 10 tahun 2006 tentang Badan Pertanahan Nasional

Kompas.com, Sengketa Tanah antar perorangan tembus 6071 Kasus. Sumber: https://properti.kompas.com/read/2018/12/18/125954021/sengketa-tanahantar-perorangan-tembus-6071-kasus, diakses 18 Juli 2020 
Dewi Arnita Sari, Sengketa Pendaftaran....

Okezone. "Ada 8.959 Sengketa Lahan Terbanyak Konflik Antar Masyarakat." 2019. Last modified 2019. Sumber: https://economy.okezone .com/read/2019/05/03/470/2051073/ada-8-959-sengketa-lahan-terbanyakkonflik-antar-masyarakat. 